\title{
Analysis of the ways of efficiency enhancement of transportation services in tourism
}

\author{
Chepurda Larysa Mykhailivna: \\ Аналіз шляхів підвищення ефективності транспортних послуг в туризмі \\ A turisztikai közlekedési szolgáltatások hatékonyságának elemzési módjai
}

Туризм - це одна з найбільш динамічних у своєму розвитку галузей економіки світу. Туристичний бізнес стає дедалі все більш привабливим не тільки для споживачів послуг, а й для підприємців, що обумовлено мінімальними вкладами на створення і розвиток туристичного бізнесу, швидкою окупністю витрат, постійним попитом на туристичні послуги тощо.

\section{Ключові слова: туризм,транспортні послуги, ефективність}

A turizmus a világgazdaság egyik legdinamikusabban fejlödő területe. Köszönhetöenannak, hogy viszonylag alacsony költségü beruházás szükséges a turisztikai vállalkozások létrehozásához, magas a megtérülési ráta, a kereslet folyamatosan növekszik a turisztikai szolgáltatások iránt. A turizmus iránt így az utóbbi időben nemcsak a potenciális utazók, de a vállalkozók, köztük a szállitással foglalkozók is érdeklődnek.

Kulcsszavak: turizmus, közlekedési szolgáltatások, hatékonyság

\section{ABSTRACT}

Tourism is one of the most dynamically developing fields of the world economy. Owing to the relatively low-cost capital investment necessary to set up and develop tourism business, high levels of payback rates, constantly rising magnitude of demand for tourist services, tourism business has recently been drawing the attention of not only its potential customers, but also of entrepreneurs.

Keywords: tourism, transportation services, efficiency

Transportation provision is one of the key elements of tourism infrastructure, included in the main complex of services in the system of tourism product. Transport companies are viewed as a special form of tourism companies, which constitute the system of tourism at the tourism market.

As an integral part of the sphere of economy, transportation in itself does not manufacture any goods, being indirectly involved in their production, supplying industries with raw materials, equipment and delivering products to the consumer. Transportation expenditure is included in the final cost of the product. In certain industries transportation costs entail significant expenditure, such as, for instance, forestry and petroleum industries, where they can be reaching the point of $30 \%$ of the total production cost. Transportation is key to success in tourism, inasmuch as it is indispensable for the running of the services that are sold and bought at the world tourism market.

Thriving of tourism markets, which are incessantly generated and spread, as well as an 
adequate transportation system are one of the most important prerequisites for the efficient operation of any tourist center. Tourist service demand has accelerated the development of the transportation industry. One of the most significant factors contributing to it are the remarkable scientific and technological advances made in the transportation industry over the recent decades.

In Ukraine, an attempt at designating transportation services together with their development strategies implementation is complicated at the country's tourist market due to a number of problems, such being deficient information provision of tourism market, widely-spread illegal business, lack of clearly defined legal and regulatory framework for the management of tourism, its poorly organized infrastructure, discrepancy between the price and quality of service etc, which hinder the implementation of the aforementioned strategy at the Ukrainian market. Intensive tourism development requires close interaction with information systems, since tourism service is a product that needs immediate deliverance. Therefore, bringing the process of catering to the level of automaticity is essential at the tourism market. Since transportation services enjoy priority in the whole complex of tourism services, their efficiency applies primarily to transportation.

The number of Internet users has risen considerably over the recent years $178 \%$ of the population of the USA by the end of the previous year, $65 \%$ of Japan's population, and $69 \%$ of the population of Great Britain). Application of information and computer technology in reservation systems determines the clarity and efficiency of interaction between all participants of tourism business related to the provision of transportation services to clients.

Utilizing the information systems of reservation provides new opportunities: for the integration into the world tourism market; efficiently managing one's activity; targeting the market of tourist product; planning marketing strategy; forming preliminary lists of tourist product consumers and ensuring catering for the clients' needs, analyzing tourist product demand at various points in time etc.

It is noteworthy, that the prevailing number of online purchases worldwide is made in the USA, accounting for $75 \%$ of all bookings. Online tourist services purchase in the USA has been steadily on increase year by year. Among the services booked preference varies from $66 \%$ for flights, $22 \%$ for hotel accommodation, $9 \%$ for car rentals and, finally, $3 \%$ for cruises and rail transportation.

In Europe, consistent improvement is seen at the on-line sales and will eventually surpass the rates of reservations in the USA. The level of on-line booking is at its highest in Great Britain (38\%), followed by Germany with $22 \%$, France (12\%), Scandinavia and Benelux, Austria and Switzerland.

The lowest demand for this service can be traced in the countries of Southern Europe, namely Italy, Spain, Portugal and Greece. Flights account for the largest share of bookings (more than 62\%), hotel services account for $14 \%$, package tours - for more than $10 \%$, rail transportation - more than $9 \%$, car rental service - about 3\%.

At present, computer reservation systems (CRS) have proven to be by far the most effective means owing to their high reliability, accuracy, efficiency, multifunctional character, fast information processing and transmission to other members of tourism market, a high degree of information security, and the ability to integrate into the global systems through Internet gateways.

CRS utilization offers enormous benefits to all those involved in tourism business.

Currently, the top global reservation systems are Sabre, Galileo, Amadeus, Worldspan, Fidelio, Gabrielle etc. (Fig.1).

Consequently, the most significant market share is held by Galileo (about 40\%), Sabre ranks second, with Amadeus and Worldspan, more common at the domestic market, following them. In essence, tourism industry provides most of its transportation services to its customers by means of CRS. Furthermore, CRS offers 
benefits not only to travel agencies, but also to all those concerned with tourism market and helps to eliminate such problems as inaccurate information related to destinations, information delay, inaccurate data on travelers, inaccessibility of remote tourist destinations etc.

Figure 1.Quantity of reservations made via CRS (once a year)

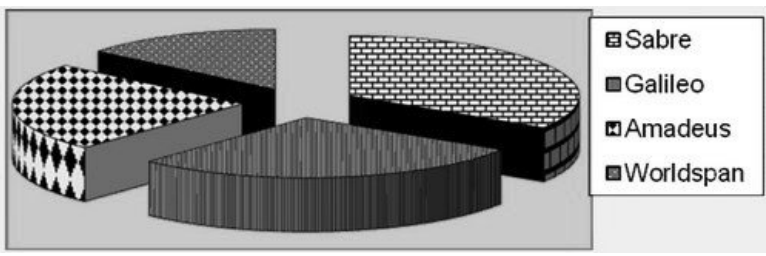

Having analyzed and summarized the criteria of efficiency of transportation services in tourism and considered its inherent features, as well as the complex nature of forecasting the price structure of such a complicated market, the following ways of enhancing the efficiency of transportation services are proposed: segmentation of the tourism market on the basis of transportation expenditure with the aim of singling out the necessary segment; improving the personnel's competence; offering special training to the personnel on the application of the new information technologies of transportation services (CRS); validation of the data provided by competitors with regard to the specific nature of transportation services; focusing on the potential consumer of the services; designing plans for corporate customer service; maintaining close contact with those interested in the enhancement of the transportation service market in Ukraine; elaborating unified schemes of cooperation with the relevant providers of transportation services at their primary market.

Thorough analysis of the current state of the tourism market suggests that transportation exerts considerable impact on the economy and development of the tourism market. Hence, further research is needed into the problem of the role of transportation system in tourism and elaboration of optimized schemes of transportation services in certain regions of the world etc.

\section{References}

[1.] Ильина Е.Н. Организация железнодорожных перевозок [текст]: - М.: Советский спорт, 2011. - 383 с.

[2.] Морозов М.А. Информационные технологии в социально-культурном сервисе и туризме - 2-е изд., стереотип [текст]: - М.: Изд. центр «Академия», 2012. - 240 с.

[3.] Гуляев В.Г. Организация туристских перевозок [текст]: - М.: Финансы и статистика, 2011. - 319 с.

[4.] Бізнес-портал. [Електронний ресурс]. - Доступний http://www.business.if.ua/themes/ 